\title{
DIFFERENT STRATEGIES TO ESTIMATE THE COMMERCIAL VOLUME OF Anadenanthera colubrina (Vell.) Brenan
}

\author{
Samuel de Pádua Chaves e Carvalho ${ }^{1}$, Adriano Ribeiro de Mendonça ${ }^{2}$, Mariana Peres de Lima ${ }^{3}$, Natalino Calegario ${ }^{4}$
}

(received: April 15, 2009; accepted: June 30, 2010)

\begin{abstract}
This work aimed to evaluate the use of traditional models, profile and relative height method, for estimating the commercial volume of Anadenanthera colubrina (Vell.) Brenan. Data were obtained from scaling of separate lengths of the stem of 22 trees, using Smalian's method. Tree stems were measured $0.1 \mathrm{~m}, 0.30 \mathrm{~m}, 0.70 \mathrm{~m}, 1.0 \mathrm{~m}, 1.30 \mathrm{~m}$ above the ground and then every $1 \mathrm{~m}$. For purposes of method assessment and comparison, statistics were used that include percent standard error, bias, standard deviation of differences, in addition to graphic interpretation of residuals. Assessments showed that Stoate's model is the most accurate, followed by Schumacher's model. They also showed that the linearized Schumacher's model reduced accuracy by an average $0.32 \%$ and that the relative height method was biased in this study.
\end{abstract}

Key words: Volume equations, taper, relative height.

\section{DIFERENTES ESTRATÉGIAS PARA ESTIMAR O VOLUME COMERCIAL DE Anadenanthera colubrina (Vell.) Brenan}

\begin{abstract}
RESUMO: Objetivou-se, neste trabalho, avaliar o uso de modelos tradicionais, de perfil e o método da altura relativa, na estimativa do volume comercial de Anadenanthera colubrina (Vell.) Brenan. Os dados foram obtidos da cubagem rigorosa de 22 árvores através do método de Smalian. Os fustes das árvores foram medidos a 0,1m;0,30m;0,70m; 1,0m; 1,30m e posteriormente de 1 em Im. Para fins de avaliação e comparação dos métodos, foram aplicadas estatísticas de: Erro padrão percentual, Bias, Desvio Padrão das Diferenças, além da interpretação gráfica dos resíduos. Com base nestas avaliações pôde-se concluir que o modelo de Stoate é o mais preciso, seguido pelo modelo de Schumacher. Conclui-se também que a linearização do modelo de Schumacher reduziu sua precisão 0,32\% em média e que o método da altura relativa foi tendencioso neste estudo.
\end{abstract}

Palavras-chave: Equações de volume, afilamento, altura relativa.

\section{INTRODUCTION}

The growing demand for timber for a wide variety of purposes also brings the imminent danger of timber shortage. This growing demand intensifies pressures on native forests, leading to increasingly predatory exploration which, in most cases, lacks the use of suitable measurement and management techniques.

Belonging to the Leguminosae-Mimosoideae family, s Anadenanthera colubrina (Vell.) Brenan, also known as angico, is a native species with multiple uses, including building construction, hydraulic systems, railroad crossties, floor boards, wood structures etc., on account of its inherent characteristics of high density $\left(0.93 \mathrm{~g} / \mathrm{cm}^{3}\right)$, compaction and thick, reverse grain composition, which confer high durability on products. It can reach 12 to $15 \mathrm{~m}$ in high, and 30 to $50 \mathrm{~cm}$ in diameter (LORENZI 2002).

Obtaining timber volume can be crucial in forestry, particularly for time and cost reduction but also for accuracy reasons. There are several ways of obtaining this volume in both standing and felled trees, with studies demonstrating that Huber's method is the most accurate for felled trees (MACHADO et al. 2006).

It is a common practice to estimate volume via quantitative methods, using stochastic models. In forest management and mensuration, models are used to estimate volume with limited data from each plot, as obtained from field observations (SPATHELF \& NUTTO 2000). The most popular volumetric models in forestry

\footnotetext{
${ }^{1}$ Forest Engineer, Ph.D. candidate by the Forest Resource Graduate Program of Escola Superior de Agricultura Luiz de Queiroz - Av. Pádua Dias, 11 - 13418-900 - Piracicaba, SP - samukajm@yahoo.com.br

${ }^{2}$ Forest Engineer, Dr. Professor of Forest Engineering - Universidade Estadual de Goiás - Unidade Universitária de Ipameri - Rodovia GO 330, Km 241 - Anel Viário - 75780-000 - Ipameri, GO - ribeiroflorestal@yahoo.com.br

${ }^{3}$ Forest Engineer, Professor, M.Sc. in Forest Engineering - Universidade Federal do Mato Grosso - Campus Sinop - 78550-000 - Sinop, MT, Brasil - marianaperes@cpd.ufmt.br

${ }^{4}$ Forest Engineer, Dr. Professor of Forest Sciences - Departamento de Ciências Florestais - Universidade Federal de Lavras - $37200-000$ Lavras, MG - calegari@dcf.ufla.br
}

Cerne, Lavras, v. 16, n. 3, p. 399-406, jul./set. 2010 
are probably Spurr's, Stoate's, and Schumacher and Hall's models.

Another highly accurate, very applicable procedure to obtain tree volume is by using profile or taper models which, according to Lima (1986), are a mathematical way of describing stem profile. These models are based on solid of revolution techniques that derive volume within a finite bound of integration.

A currently used methodology for describing stem profile is the geometric or relative height method. According to Andrade (2001), this method is based on the postulate that 'there is a specific point between the diameter $1.30 \mathrm{~m}$ above ground (DBH) and total height of a tree which, after dividing the tree into two intervals, allows minimizing taper estimate errors, a point known as relative height'. This point, according to Andrade (2001), is derived by the expression $h r=\frac{(h t-2)}{2}$. Results found by Leite \& Andrade (2002) while studying Eucalyptus stands demonstrate the efficiency of this method without the need for volumetric equations in order to conduct forest inventories.

Studies being scarce on the species in question, and considering its high yield and use potential, this work aims to evaluate three different methodologies for estimating the commercial volume of Anadenanthera colubrina (Vell.) Brenan.

\section{MATERIAL AND METHODS}

\subsection{Study site}

The study site is about 2.36 ha in area and lies in the campus of the Federal University of Lavras (MG). It comprises a heterogeneous stand with trees at different ages, with predominance of species Anadenanthera colubrina (Vell.) Brenan.

Historically, species Anadenanthera colubrina was introduced by way of an experiment attempting to verify the effect of shading on coffee plantations. About thirty-five years ago, after verifying that where coffee plantations were fully exposed to the sun the yield was $40 \%$ higher than yield in shaded areas, the experimental area was abandoned. Then natural regeneration followed, with predominance of Anadenanthera colubrina, and according to Nascimento et al. (2009), the area has now 25 families divided into 66 vegetal species. The local climate according to Köppen classification is ' $\mathrm{Cwb}$ ' type (temperate with mild summers and dry winters). The average annual precipitation is $1,493.2 \mathrm{~mm}$ and the average annual temperature is $19.3^{\circ} \mathrm{C}$, with $66 \%$ of the precipitation occurring between November and February (VILELA \& RAMALHO 1979).

\subsection{Data collection and analysis}

22 trees were cubed using Smalian's method. Stems were measured $0.1 \mathrm{~m}, 0.30 \mathrm{~m}, 0.70 \mathrm{~m}, 1.0 \mathrm{~m}, 1.30 \mathrm{~m}$ above the ground, and then every $1 \mathrm{~m}$. Additionally, measurements were taken of the commercial height, which is the height of a stem up until the first bifurcation, and also of the total height.

The number of cubed trees by diameter class and height is illustrated in Table 1.

Statistical software $\mathrm{R}$ was used for data analysis.

The variation in diameter according to height, characterizing tree tapering, is illustrated in Figure 1.

According to Figure 1, a great variation is noted in data and in shape for the species in question. Some of the

Table 1 - Tree distribution by diameter class and height.

Tabela 1 - Distribuição por classe de diâmetro e altura das árvores amostradas.

\begin{tabular}{|c|c|c|c|c|c|c|}
\hline \multirow{2}{*}{$\begin{array}{l}\text { DBH Class Midpoint } \\
(\mathrm{cm})\end{array}$} & \multicolumn{5}{|c|}{ Height Class Midpoint (m) } & \multirow{2}{*}{ Tota } \\
\hline & 7.5 & 12.5 & 17.5 & 22.5 & 27.5 & \\
\hline 7.5 & 4 & 2 & - & - & - & 6 \\
\hline 12.5 & - & 3 & - & - & - & 3 \\
\hline 17.5 & - & 1 & 2 & - & - & 3 \\
\hline 22.5 & 1 & - & 2 & 2 & - & 5 \\
\hline 27.5 & - & - & - & 2 & - & 2 \\
\hline 32.5 & - & - & - & 1 & 2 & 3 \\
\hline Total & 5 & 6 & 4 & 5 & 2 & 22 \\
\hline
\end{tabular}

Cerne, Lavras, v. 16, n. 3, p. 399-406, jul./set. 2010 


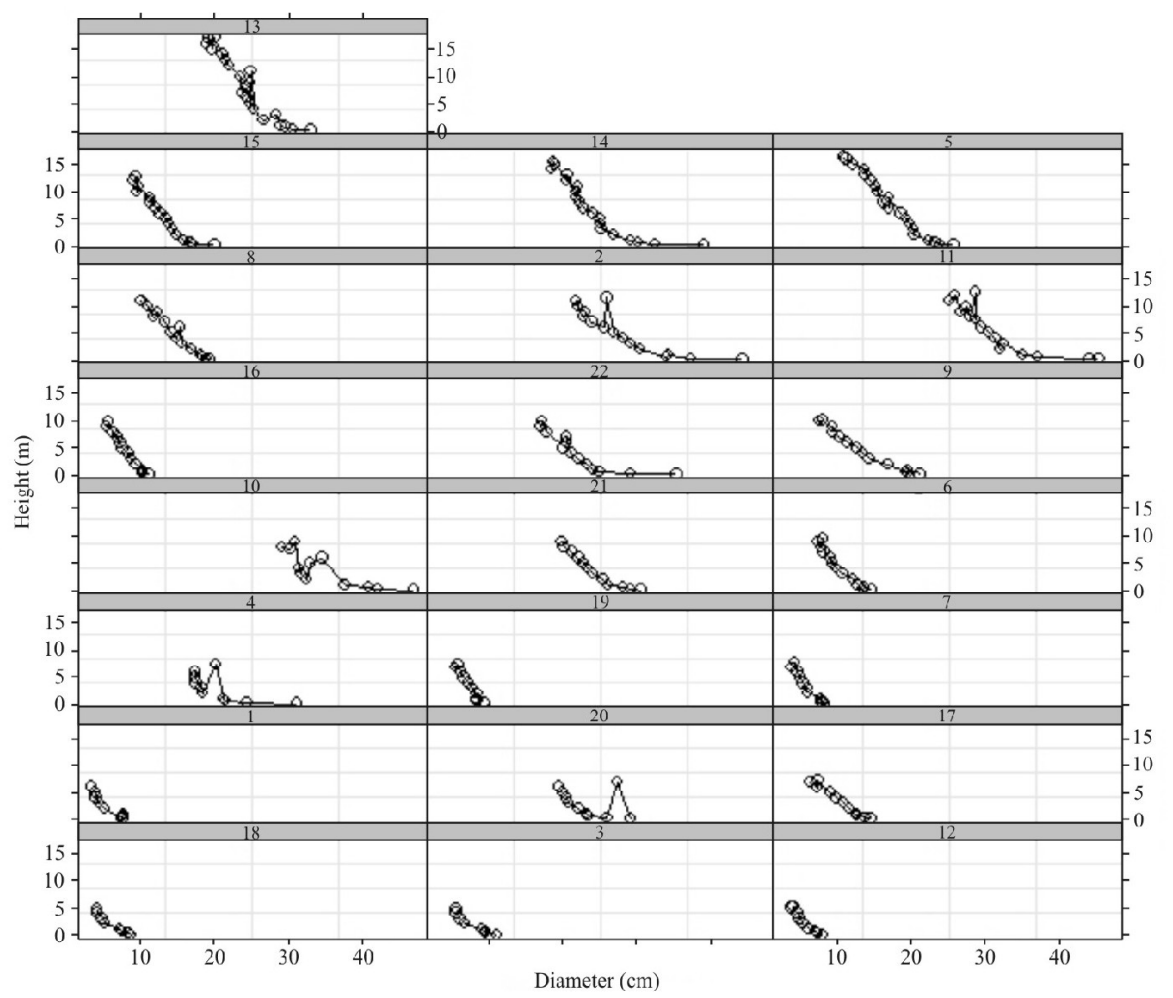

Figure 1 - Profile of 22 sample trees.

Figura 1 - Perfil das 22 árvores amostradas.

models and methods capable of capturing such variations are addressed in this work.

\subsection{Methodologies applied to estimate commercial volume}

Volumetric models, taper functions and the relative height method were evaluated, in order to estimate the commercial volume of species Anadenanthera colubrina.

\subsubsection{Volumetric models}

a) Schumacher \& Hall's model

$V_{i}=\beta_{0} D B H_{i}^{\beta_{1}} H c_{i}^{\beta_{2}} \varepsilon_{i}$

where: $\mathrm{V}_{\mathrm{i}}=$ commercial volume of $\mathrm{i}$-th tree $\left(\mathrm{m}^{3}\right) ; D B H_{i}=$ diameter $1.30 \mathrm{~m}$ above ground of $\mathrm{i}$-th tree $(\mathrm{cm}) ; H c_{i}=$ commercial height of $\mathrm{i}$-th tree $(\mathrm{m})$; $\ln =$ natural logarithm; $\beta_{i s}=$ parameters to be estimated; $\varepsilon_{\mathrm{i}}=$ random error.

b) Linearized Schumacher \& Hall's model

$$
\ln \left(V_{i}\right)=\ln \left(\beta_{0}\right)+\beta_{1} \ln \left(D B H_{i}\right)+\beta_{2} \ln \left(H c_{i}\right)+\varepsilon_{i}
$$

c) Stoate's model

$V_{i}=\beta_{0}+\beta_{1} D B H_{i}^{2}+\beta_{2} H c_{i}+\beta_{3} D B H_{i}^{2} H c_{i}+\varepsilon_{i}$

Figure 2 indicates volume trend as a function of input variables diameter and commercial height.

\subsubsection{Taper functions}

a) Polynomial of degree 5 (SCHOEPFER 1966)

$d_{i j}=D B H_{i} \beta_{0}+D B H_{i} \beta_{1}\left(\frac{h_{i j}}{H_{i}}\right)+D B H_{i} \beta_{2}\left(\frac{h_{i j}}{H_{i}}\right)^{2}+D B H_{i} \beta_{3}\left(\frac{h_{i j}}{H_{i}}\right)^{3}+$

$+D B H_{i} \beta_{4}\left(\frac{h_{i j}}{H_{i}}\right)^{4}+D B H_{i} \beta_{5}\left(\frac{h_{i j}}{H_{i}}\right)^{5}+\varepsilon_{i}$

where: $d_{i j}=$ diameter of $\mathrm{i}$-th tree in $\mathrm{j}$-th position $\mathrm{h}_{\mathrm{ij}}(\mathrm{cm}) ; h_{i j}=$ commercial height of $\mathrm{i}$-th tree in $\mathrm{j}$-th position $(\mathrm{m}) ; H_{i}=$ total height of $\mathrm{i}$-th tree $(\mathrm{m}) ; D B H_{i}=$ diameter $1.30 \mathrm{~m}$ above ground of i-th tree $(\mathrm{cm})$.

Cerne, Lavras, v. 16, n. 3, p. 399-406, jul./set. 2010 

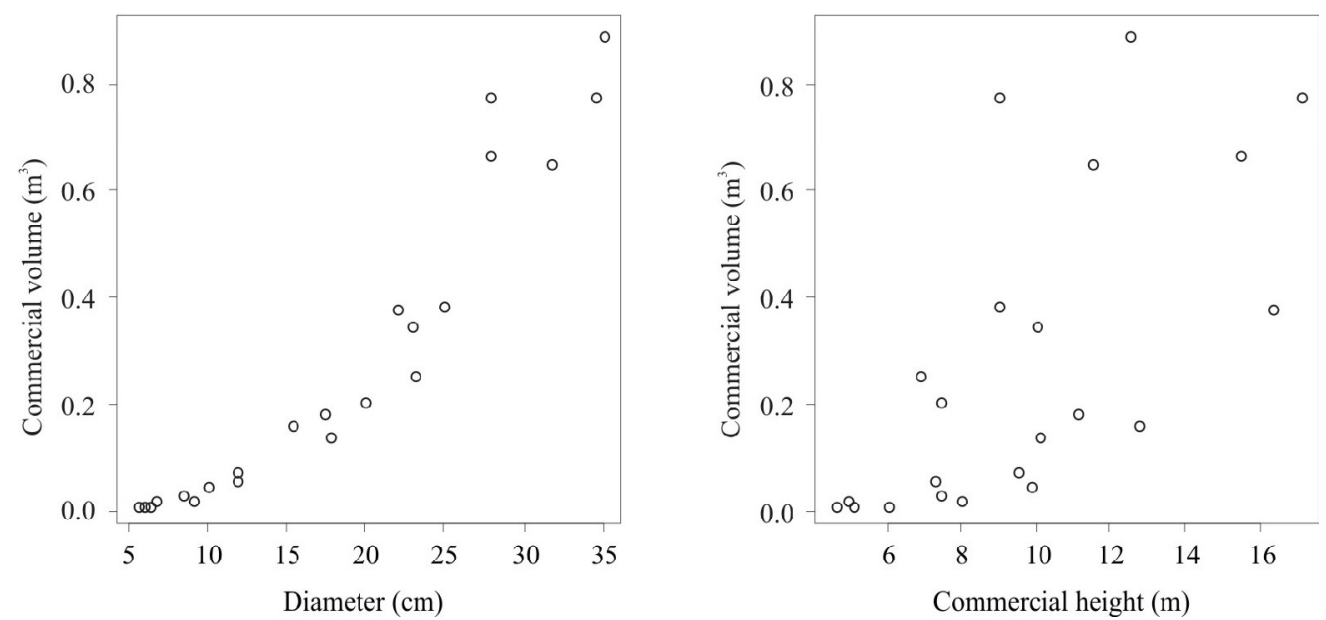

Figure 2 - Tendency of diameter and height variables as a function of commercial volume.

Figura 2 - Tendência das variáveis diâmetro e altura, em função do volume comercial.

With the polynomial, volume was derived by integrating the following equation:

$$
\hat{V}_{j}=K \int_{h_{1}}^{h_{2}} d_{i j}^{2} \delta h
$$

where: $\hat{V}_{j}=$ estimated volume of $\mathrm{j}$-th tree $\left(\mathrm{m}^{3}\right) ; K=\frac{\pi}{40000}$; $h_{1}$ and $h_{2}=$ bounds of integration (m).

b) Demaerschalk's model (1972)

$$
\begin{aligned}
& \left(\frac{d_{i j}}{D B H_{i}}\right)^{2}=10^{2 \beta_{0}} D B H_{i}^{2 \beta_{1}-2}\left(H_{i}-h_{i j}\right)^{2 \beta_{2}} H_{i}^{2 \beta_{3}}+\varepsilon_{i} \\
& \hat{V}_{j}=\frac{K 10^{2 \hat{\beta}_{0}} D B H_{i}^{2 \hat{\beta}_{1}} H_{i}^{2 \hat{\beta}_{3}}\left[\left(H_{i}-h_{i j}\right)^{2 \hat{\beta}_{2}+1}-\left(H_{i}-h_{i+1 ; j}\right)^{2 \hat{\beta}_{2}+1}\right]}{2 \hat{\beta}_{2}+1}
\end{aligned}
$$

\subsubsection{Relative height method}

Andrade (2001) developed the relative height method in his formulation of $A C$ (angular coefficients), as follows:

$$
\begin{gathered}
A C_{I i}=\frac{1.3-h_{0,1 i}}{\left(D B H_{i}-d_{h_{0,3 i}}\right) / 2} \\
A C_{I I i}=\frac{1.3-h r_{i}}{\left(D B H_{i}-d_{h h_{i}}\right) / 2}
\end{gathered}
$$

$A C_{I I I i}=\frac{h r_{i}-h t_{i}}{d_{h r_{i}} / 2}$

The following 'taper' equations were generated: For $0.1<h_{i}<1.3 \mathrm{~m}$;

$d_{h i}=\frac{2 h_{i}-2.6}{A C_{l i}}+D B H_{i}$

For $1.3<h_{i}<\mathrm{hr}$;

$d_{h i}=\frac{2 h_{i}-2.6}{A C_{I I i}}+D B H_{i}$

For $\mathrm{hr}<h_{i}<\mathrm{ht}$;

$d_{h i}=\frac{h_{i}-1.3}{A C_{I I i}}+\frac{h_{i}-h t_{i}}{A C_{I I I i}}+\frac{D B H_{i}}{2}$

where:

$A C_{k i}=$ angular coefficient of straight line passing by $k$-th interval I, II, III in the i-th tree;

$d_{(0,0 \leq h i \leq h)}=$ diameter at $\mathrm{h}_{\mathrm{i}-\mathrm{th}}$ desired height $(\mathrm{cm})$;

$h_{0,1}=$ stump height, corresponding to $0.1 \mathrm{~m}$;

$h_{i}=$ commercial height $(\mathrm{m})$;

$h r_{2}$ refers to commercial height for this study as the method was adapted to the specific situation.

Relative height is determined by the expression:

$h r=\frac{(h t-2)}{2}$ 
where:

$h r=$ relative height $(\mathrm{m})$;

$h t=$ total height $(\mathrm{m})$.

After estimating diameters at different portions of the stem, trees were cubed using Smalian's method.

\subsection{Method diagnosis}

Each methodology was tested for accuracy using the following statistics:

a) Residual standard error

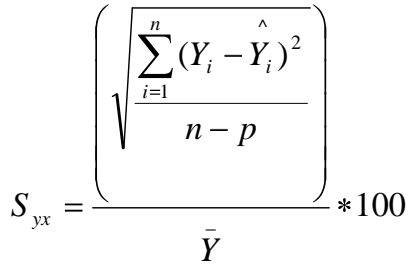

where: $\operatorname{Syx}=$ standard error of estimate $(\%) ; \hat{Y}_{i}=$ estimated volume $\left(\mathrm{m}^{3}\right) ; \mathrm{Y}_{\mathrm{i}}=$ observed volume $\left(\mathrm{m}^{3}\right) ; \mathrm{n}=$ number of observations; $\mathrm{p}=$ number of parameters; $\bar{Y}=$ average observed volume $\left(\mathrm{m}^{3}\right)$.

b) Bias (B)

$$
B=\frac{\sum_{i=1}^{n} Y_{i}-\sum_{i=1}^{n} \hat{Y}_{i}}{n}
$$

c) Standard deviation of differences (SDD)

$S D D=\sqrt{\frac{\sum_{i=1}^{n} d_{i}^{2}-\frac{\left(\sum_{i=1}^{n} d_{i}\right)^{2}}{n}}{n-p}}$

where:

$d_{i}=\left(Y_{i}-\hat{Y}_{i}\right)$

Based on test results, methodologies were ordered by degree of accuracy, attributing scores 1 to 6 (LIMA 1986, MENDONÇA et al. 2007). The most accurate method is the one presenting the lowest aggregate score.

A visual analysis of residual dispersion was also carried out.

\section{RESULTS AND DISCUSSION}

Table 2 presents parameter estimates for each proposed model, in order to estimate the commercial volume of Anadenanthera colubrina.

From Table 2 it is noted that all fitted parameters were significant at the $5 \%$ significance level, being therefore indispensable for estimating volume.

\subsection{Graphic residual analysis}

Figure 3 presents a graphic residual analysis of volume estimation, as a function of percent error.

Table 2 - Parameter estimates for each proposed model in order to estimate volume, with their respective significance levels.

\begin{tabular}{|c|c|c|c|c|c|c|c|}
\hline Model & Description & $\beta_{0}$ & $\beta_{1}$ & $\mathrm{~B}_{2}$ & $\beta_{3}$ & $B_{4}$ & $B_{5}$ \\
\hline \multirow{2}{*}{1} & Estimate & 0.00008202 & 2.140 & 0.6865 & & & \\
\hline & $\operatorname{Pr}(>|t|)$ & 0.01 & $<0.001$ & $<0.001$ & & & \\
\hline \multirow{2}{*}{2} & Estimate & -9.51387 & 2.15755 & 0.69823 & & & \\
\hline & $\operatorname{Pr}(>|t|)$ & $<0.001$ & $<0.001$ & $<0.001$ & & & \\
\hline \multirow{2}{*}{3} & Estimate & 0.01088 & 0.0002197 & -0.003567 & 0.00004518 & & \\
\hline & $\operatorname{Pr}(>|t|)$ & 0.05 & 0.001 & 0.05 & $<0.001$ & & \\
\hline \multirow{2}{*}{4} & Estimate & 1.17064 & -5.34725 & 27.98789 & -69.53288 & 75.70947 & -29.19820 \\
\hline & $\operatorname{Pr}(>|t|)$ & $<0.001$ & $<0.001$ & $<0.001$ & $<0.001$ & 0.001 & 0.01 \\
\hline \multirow{2}{*}{5} & Estimate & 0.12382 & 0.97736 & 0.75801 & -0.78514 & & \\
\hline & $\operatorname{Pr}(>|t|)$ & 0.001 & 0.001 & 0.001 & 0.001 & & \\
\hline
\end{tabular}

Tabela 2 - Estimativa dos parâmetros dos modelos propostos para estimativa volumétrica com os respectivos níveis de significância.

Where: $1=$ Schumacher; $2=$ Linearized Schumacher; 3=Stoate; 4=Schoepfer; 5=Demaerschalk 

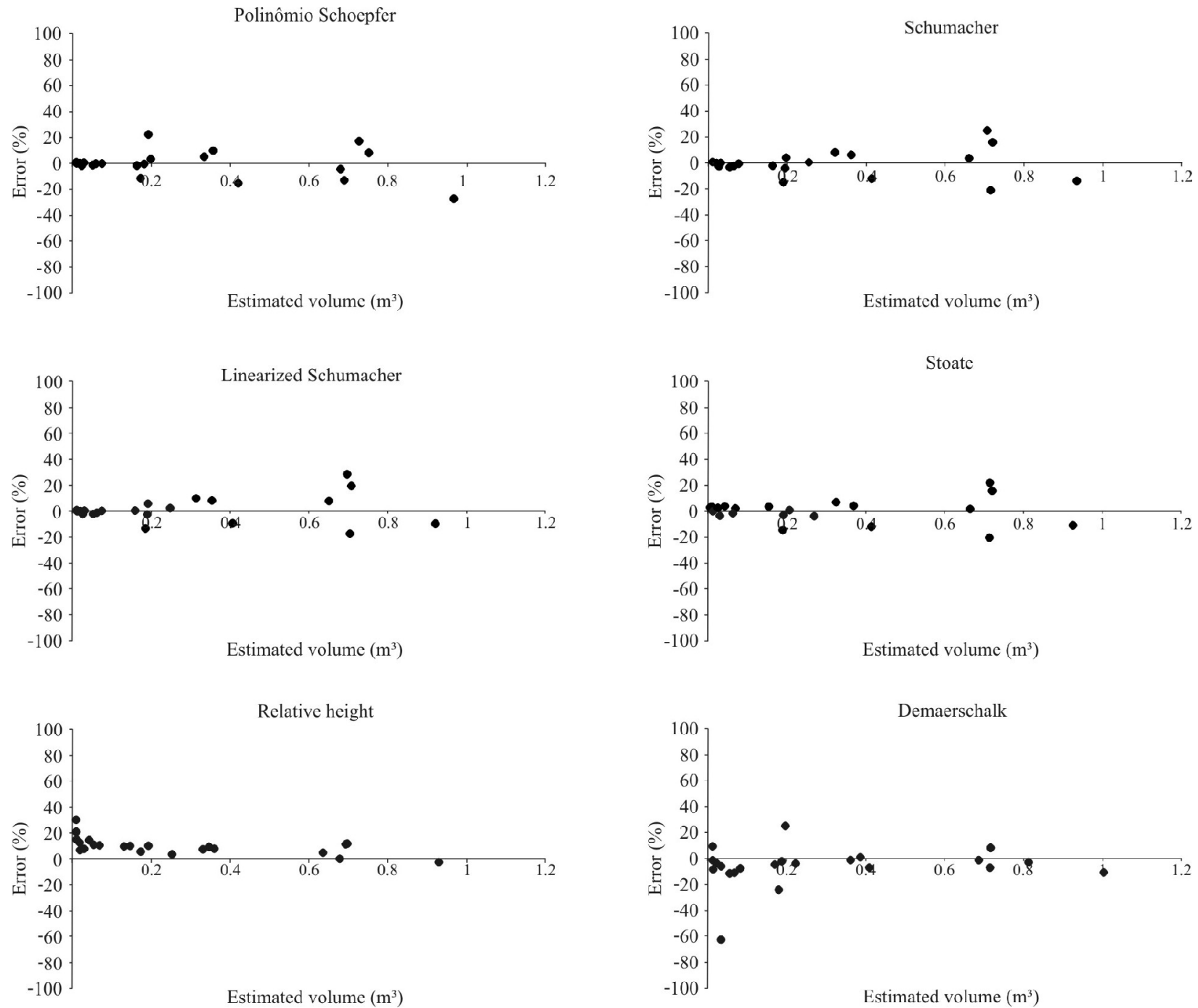

Figure 3 - Graphic distribution of percent residuals for different methodologies in volume estimation.

Figura 3 - Distribuição gráfica dos resíduos porcentuais para as diferentes metodologias propostas na estimativa volumétrica.

It can be noted that virtually every method presented good residual distribution, with mean errors tending to zero and identically distributed, except for the relative height method, which tended to underestimate volume values. Despite being applied only to Pinus and Eucalyptus stands before, the relative height method proved applicable in this study, according to statistics in Table 3.

Stoate's and Schumacher's models, in original and linearized forms, presented better residual distribution, with errors being overall distributed randomly around zero. Chichorro et al. (2003) concluded that the linearized
Schumacher's model presents a good residual distribution, normally distributed and with a high $\mathrm{R}^{2}$ value.

\subsection{Methodology accuracy}

Table 3 presents statistical results for the proposed methodologies to estimate the commercial volume of Anadenanthera colubrina.

When percent standard error is analyzed, which is a commonly applied statistic in modeling works, the most suitable methodology is Stoate's linear model, followed by Schumacher's model.

Cerne, Lavras, v. 16, n. 3, p. 399-406, jul./set. 2010 
Table 3 - Statistics applied to different methodologies to estimate volume, with their respective scores.

Tabela 3 - Estatísticas aplicadas às diferentes metodologias propostas na estimativa volumétrica com as respectivas atribuições de notas.

\begin{tabular}{lcccc}
\hline Methodology & Syx (\%) & Bias & SDD & Total \\
\hline Schumacher (nonlinear) & $11.22(2)$ & $-0.0013(3)$ & $0.0311(3)$ & 8 \\
Schumacher (linearized) & $11.54(3)$ & $0.0041(4)$ & $0.0317(4)$ & 11 \\
Stoate & $10.80(1)$ & $-0.0001(1)$ & $0.0300(2)$ & 4 \\
Polynomial & $12.35(5)$ & $0.0004(2)$ & $0.0343(5)$ & 12 \\
Relative Height & $12.30(4)$ & $0.0182(6)$ & $0.0287(1)$ & 11 \\
Demaerschalk & $12.67(6)$ & $-0.0070(5)$ & $0.0350(6)$ & 17 \\
\hline
\end{tabular}

When ranking was done and final scores were analyzed, it was noted that best accuracy is provided by Stoate's linear model, followed by Schumacher's model and the relative height method respectively. Couto \& Bastos (1987) suggest using Spurr's combined variable equation to estimate the volume of Eucalyptus sp intended for pulp production in São Paulo state. Similar results were found by Couto \& Vettorazzo (1999).

The linenarization of Schumacher's model led to increased deviations on average, and this fact can be explained by loss of information during logarithmic processing.

A connection can be made between statistical analyses and the graphic residual analysis, observing the good distribution of residuals for methodologies with best accuracy, except for the relative height method which presents a degree of bias, explained by the fact that it is a nonparametric method.

\section{CONCLUSIONS}

It can be concluded from the methodologies used that all methods are applicable to estimate the commercial volume of Anadenanthera colubrina.

The good accuracy of Stoate's model is explained by high correlation between diameter, height and the interaction diameter-height with volume.

Despite not being the best alternative to estimate the commercial volume of species Anadenanthera colubrina, more emphasis should be given to profile models, as they can be a fundamental tool when multiple products are to be obtained from a stem, as is the case with this species.

\section{BIBLIOGRAPHICAL REFERENCES}

ANDRADE, V. C. L. Um método para descrever o perfil do tronco em árvores de eucalipto utilizando geometria analítica. 2001. 86 p. Dissertação (Mestrado em Engenharia Florestal) - Universidade Federal de Viçosa, Viçosa, 2001.

CHICHORRO, J. K.; RESENDE, J. L. P.; LEITE, H. G. Equações de volume e de taper para quantificar multiprodutos da madeira em floresta atlântica. Revista Árvore, Viçosa, v. 27, n. 6, p. 799809, 2003.

COUTO, H. T. Z.; BASTOS, N. L. M. Modelos de equações de volume e relações hipsométricas para plantações de Eucalyptus no estado de São Paulo. IPEF, n. 37, p. 33-44, dez. 1987.

COUTO, H. T. do; VETTORAZZO, S. C. Seleção de equações de volume e peso seco para Pinus taeda. Cerne, Lavras, v. 5, n. 1, p. 69-80, 1999.

DEMAERSCHALK, J. P. Converting volume equations to compatible taper equations. Forest Science, Amsterdam, v. 18, n. 3, p. 241-245, 1972.

LEITE, H. G.; ANDRADE, V. C. L. Um método para condução de inventários florestais sem o uso de equações volumétricas.

Revista Árvore, Viçosa, v. 26, n. 3, p. 321-328, 2002.

LIMA, F. S. Análise de funções de "taper" destinadas à avaliação de multiprodutos de árvores de Pinus elliiotti. 1986. 79 p. Dissertação (Mestrado em Engenharia Florestal) Universidade Federal de Viçosa, Viçosa, 1986.

LORENZI, H. Árvores brasileiras: manual de identificação e cultivo de plantas arbóreas do Brasil. 4. ed. Nova Odessa: Instituto Plantarum de Estudos da Flora, 2002. v. 2.

Cerne, Lavras, v. 16, n. 3, p. 399-406, jul./set. 2010 
MACHADO, S. A.; TÉO, S. J.; URBANO, E.; FIGURA, M. A.; SILVA, L. C. R. Comparação de métodos de cubagem absolutos com o volume obtido pelo xilômetro para bracatinga (Mimosa scabrella). Cerne, Lavras, v. 12, n. 3, p. 239-253, 2006.

MENDONÇA, A. R. de; SILVA, G. F. da; OLIVEIRA, J. T. da S.; NOGUEIRA, G. S. Avaliação de funções de afilamento visando a otimização de fustes de Eucalyptus sp. para multiprodutos. Cerne, Lavras, v. 13, n. 1, p. 71-82, 2007.

NASCIMENTO, G. D.; PIFANO, D. S.; LIMA, M. P. de; CALEGARIO, N. Floristic aspects and diversity of regenerated arboreal species under a stand of Anadenanthera peregrina SPEG. Cerne, Lavras, v. 15, n. 2, p. 187-195, 2009.

SCHÖEPFER, W. Automatisierung des Massen, Sorten und Wertberechnung stenender Waldbestande Schriftenreihe Bad. [S.1.]: Wurtt-Forstl, 1966. No page.

SPATHELF, P.; NUTTO, L. Modelagem aplicada ao crescimento e produção florestal. Santa Maria: UFSM, 2000.

VILELA, E. A.; RAMALHO, M. A. P. Análise das temperaturas e precipitações pluviométricas de Lavras, Minas Gerais. Ciência e Prática, Lavras, v. 3, n. 1, p. 71-79, 1979.

Cerne, Lavras, v. 16, n. 3, p. 399-406, jul./set. 2010 